DOI: 10.1136/annrheumdis-2017-eular.1122

\section{SAT0592 EFFECT OF INTERFERENTIAL CURRENT THERAPY IN PATIENTS WITH SUBACROMIAL IMPINGEMENT SYNDROME: A RANDOMIZED, DOUBLE-BLIND, PLACEBO-CONTROLLED STUDY}

T. Nazligul, P. Akpinar, I. Aktas, F. Unlu Ozkan, H. Cagliyan. Department of Physical Medicine and Rehabilitation, Fatih Sultan Mehmet Education and Research Hospital, Istanbul, Turkey

Background: Shoulder pain is one of the most common types of musculoskeletal pain in the adult population. Subacromial impingement syndrome (SIS) has been reported to be the most frequent etiologic factor for shoulder pain (1). A conservative approach comprising non-steroid anti-inflammatory drugs (NSAID), subacromial injections, exercise, and several physical therapy agents is recommended as the first step treatment for SIS (2). Although interferential current (IFC) is a common electrotherapeutic modality used to treat musculoskeletal pain, there isn't any randomized controlled trial investigating its clinical efficacy on SIS (3). Objectives: To investigate the effectiveness of IFC treatment in patients with SIS. Methods: In this double blind, placebo controlled study, patients with shoulder pain, who had been diagnosed SIS according to clinical evaluation and subacromial injection test were randomly assigned to the IFC or placebo groups. Exercise, cryotherapy, and NSAID were applied to the all groups. Daily 20 min per session, 5 days per week, for 2 weeks 10 sessions IFC with alternative method were applied to the IFC group while sham IFC therapy were applied to the placebo group with the same protocol. Visual analog scale (VAS), Constant Murley Scale (CMS) and Shoulder Disability Questionnaire (SDQ) were used for evaluation at baseline, post-treatment and 1 month post-treatment.

Results: A total of 60 patients were completed the study; 26 (43.3\%) were male and mean age was $50.02 \pm 9.10$ years. There was not a significant difference in demographic and clinical data of the patients between the IFC $(n=30)$ and placebo $(n=30)$ groups $(p>0.05)$. Significant improvement in all parameters was observed on post-treatment and 1 month post-treatment evaluations compared to baseline evaluations in both groups $(p<0.01)$. Comparison of the VAS, CMS and SDQ scores between the two groups did not show significant difference either pre-treatment or post-treatment $(p>0.05)$

Conclusions: This study showed that IFC treatment does not provide additional benefit to NSAID, cryotherapy and exercise program in the treatment of SIS. Further studies are needed to investigate the long-term effects of IFC therapy.

[1] Van der Windt DA, Koes BW, de Jong BA, Bouter LM. Shoulder disorders in general practice: Incidence, patient characteristics, and management. Ann Rheum Dis 1995:54(12):959-64.

[2] Merino LP, Brians'o MCC, Alarc'on GB, et al. Evaluation of the effectiveness of three physiotherapeutic treatments for subacromial impingement syndrome: a randomised clinical trial, Physiotherapy. 2016 Mar;102(1):57-63.

[3] Fuentes JP, Armijo Olivo S, Magee DJ, Gross DP. Effectiveness of Interferential Current Therapy in the Management of Musculoskeletal Pain: A Systematic Review and Meta-Analysis Phys Ther. 2010 Sep;90(9):1219-38.

Disclosure of Interest: None declared

DOI: 10.1136/annrheumdis-2017-eular.2773

\section{SAT0593 GENDER-SPECIFIC ASSOCIATIONS BETWEEN FAT MASS AND MUSCULOSKELETAL PAIN IN COMMUNITY RESIDENTS: A 3-YEAR LONGITUDINAL STUDY}

K.M. Son ${ }^{1}$, N.H. Cho ${ }^{2}$, S.H. Lim ${ }^{2}$, H.A. Kim ${ }^{3} .{ }^{1}$ Department of rheumatology., Hallym University Dongtan Sacred Heart Hospital; ${ }^{2}$ Ajou University school of Medicine; ${ }^{3}$ Hallym University Sacred Heart Hospital, Gyeonggi-Do, Korea, Republic Of

Background: Increase in fat mass is correlated with musculoskeletal pain Objectives: In this study, we sought to delineate the prospective relationship between fat mass parameters and the musculoskeletal pain in Korean community residents.

Methods: In the Korean Health and Genome Study, 1,325 participants (mean age 60.2 years, $56.2 \%$ women) who completed pain questionnaires and underwent dual $x$-ray absorptiometry to calculate body composition had 3 year follow-up data on pain. Pain was categorized according to number of pain regions. After 3 years of follow-up, subjects were classified into the followings: 1) no pain both at baseline and at 3 years (no pain), 2) any pain (one, two or more, or widespread regions) at baseline and no pain at 3 years (transient pain), 3) no pain at baseline and any pain at 3 years (new pain) 4) any pain both at baseline and at 3 years (persistent pain). 1) and 2) were grouped as no/transient pain group (no pain) and 3) and 4) as new/persistent pain group (pain)

Results: Female gender and obesity were 2 significant factors associated with the persistence or development of pain. Total fat mass and fat:muscle mass ratio were significantly correlated with pain, and the odds ratios for pain were significantly increased in subjects in the highest quartile of fat muscle ratio after adjustment among female subjects only. Among normal weight subjects, those without metabolic syndrome were less likely to belong to the pain group, especially among women.
Conclusions: The association of fat mass and pain was only significant among females

Disclosure of Interest: None declared

DOI: 10.1136/annrheumdis-2017-eular.2247

\section{SAT0594 THE EFFECT OF RADIAL EXTRACORPOREAL SHOCK WAVE THERAPY (RESWT) IN THE TREATMENT OF TRIGGER FINGER}

M. Dogru $^{1}$, S. Narin ${ }^{1}$, M. Erduran ${ }^{2} .{ }^{1}$ Department of Physiotherapy and Rehabilitation, Institute of Healty Science, ${ }^{2}$ Department of Orthopedics and Traumatology, Faculty of Medicine, Izmir, Turkey

Background: Trigger finger is a stenotic tendovaginitis characterized by hand pain and dysfunction, commonly encountered and easily recognizable (1). RESWT is frequently used in the treatment of soft tissue pathologies such as lateral epicondylitis, plantar fasciitis and calcific rotator cuff tendinitis (2-3). However, there is no study examining whether RESWT is effective on the trigger finger or not.

Objectives: The aim of this study was to investigate the effect of Radial Extracorporeal Shock Wave Therapy (RESWT) in the Treatment of Trigger Finger. Methods: This study was carried out on 16 patients (18 patient hand) who had been diagnosed with trigger finger that grade 1,2,3 according to quinnel classification. Patients were carried out as a single group. 16 patients (18 patient hand) with trigger fingers were applied to ten-sessions,twice a week of RESWT (2000 impulses, 2 bar, $10 \mathrm{~Hz}$ ). Pain scores (Numeric Pain Rating Scale - NRS), general funtional capasities (The Disabilities of the Arm, Shoulder and Hand Score (Quick-DASH)), range of motion, grip strength (GS) and pinch strenght (PS) were assessed at every week for five weeks during treatment and 3 months after treatment.

Results: 13 female and 3 male patients over 18 years of age were evaluated. In the evaluations performed every week during 10 sessions of RESWT treatment and 3 months after treatment, decrease in pain levels and increase in general functional capacity, range of motion, grip strength and pinch strength were observed in the patients treated $(p<0.001)$ (tablo 1 )

Tablo 1: Comparison of range of motion of the thump finger and 2-5. Finger, comparison of pain, grip streght, pinch streght and general functional capacity

\begin{tabular}{|c|c|c|c|c|c|c|c|}
\hline & $\begin{array}{l}\text { 1.week } \\
\text { (IQR) }\end{array}$ & $\begin{array}{c}\text { 2.week } \\
(\mathrm{IQR})\end{array}$ & $\begin{array}{l}\text { 3.week } \\
\text { ( } Q R \text { ) }\end{array}$ & $\begin{array}{l}\text { 4.week } \\
(\mathrm{QQR})\end{array}$ & $\begin{array}{l}\text { 5.week } \\
\text { (IQR) }\end{array}$ & $\begin{array}{l}\text { 3month } \\
\text { (IQR) }\end{array}$ & \\
\hline $\begin{array}{l}\text { MCF } \\
\text { lexion } \\
\text { fmzers }\end{array}$ & $\begin{array}{c}45.00 \\
(40.00: 50.00)\end{array}$ & $\begin{array}{c}48.00 \\
(40.00550 .00)\end{array}$ & $\begin{array}{c}49.00 \\
(40.00152 .00)\end{array}$ & $\begin{array}{c}50.00 \\
(40.00558 .00)\end{array}$ & $\begin{array}{c}50.00 \\
(40.00 .60 .00)\end{array}$ & $\begin{array}{c}50.00 \\
(50.00 .65 .00)\end{array}$ & 0.004 \\
\hline $\begin{array}{l}\text { TF jomt flexion } \\
\text { Thump fimger }\end{array}$ & $\begin{array}{c}15.00 \\
(00.0035 .00)\end{array}$ & $\begin{array}{c}20.00 \\
(00.00 / 42.00)\end{array}$ & $\begin{array}{c}28.00 \\
(00.00 \cdot 45.00)\end{array}$ & $\begin{array}{c}39.50 \\
(00.0050 .00)\end{array}$ & $\begin{array}{c}45.00 \\
(00.00 .60 .00)\end{array}$ & $\begin{array}{c}55.00 \\
(00.00 .60 .00)\end{array}$ & 20.001 \\
\hline $\begin{array}{ll}\text { MCF } & \text { joint } \\
\text { dexion } & 2.5 \\
\text { fanger }\end{array}$ & $\begin{array}{c}80.00 \\
(50.0090 .00)\end{array}$ & $\begin{array}{c}80.00 \\
(50.00 .90 .00)\end{array}$ & $\begin{array}{c}82.50 \\
(52.00,90.00)\end{array}$ & $\begin{array}{c}82.50 \\
(54.0090 .00)\end{array}$ & $\begin{array}{c}82.50 \\
(55.00 .90 .00)\end{array}$ & $\begin{array}{c}90.00 \\
(60.00 .90 .00)\end{array}$ & 80.001 \\
\hline $\begin{array}{l}\text { PIF jomt Alexion } \\
2-5 \text { fimger }\end{array}$ & $\begin{array}{c}100.00 \\
(40.00 / 110.00)\end{array}$ & $\begin{array}{c}100.00 \\
(50.00 / 113.00)\end{array}$ & $\begin{array}{c}100.00 \\
(55.00 / 115.00)\end{array}$ & $\begin{array}{c}100.00 \\
(65.00 / 118.00)\end{array}$ & $\begin{array}{c}100.00 \\
(70.00 / 120.00)\end{array}$ & $\begin{array}{c}110.00 \\
(90.00 / 120.00)\end{array}$ & 0.001 \\
\hline $\begin{array}{l}\text { DIF jomt Alexion } \\
2.5 \text { finger }\end{array}$ & $\begin{array}{c}50.00 \\
(20.0075 .00)\end{array}$ & $\begin{array}{c}53.50 \\
(20.00755 .00)\end{array}$ & $\begin{array}{c}60.00 \\
(30.00777 .00)\end{array}$ & $\begin{array}{c}61.50 \\
(40.0077 .00)\end{array}$ & $\begin{array}{c}67.50 \\
(50.00 .80 .00)\end{array}$ & $\begin{array}{c}70.00 \\
(60.00 .85 .00)\end{array}$ & $<0.001$ \\
\hline NRS & $\begin{array}{c}7.00 \\
(.00 / 10.00)\end{array}$ & $\begin{array}{c}6.00 \\
(.007 .00)\end{array}$ & $\begin{array}{l}4.00 \\
(.007 .00)\end{array}$ & $\begin{array}{c}3.00 \\
(.007 .00)\end{array}$ & $\begin{array}{l}2.00 \\
(.007 .00)\end{array}$ & $\begin{array}{c}.00 \\
(.007 .00)\end{array}$ & $<0.001$ \\
\hline GS & $\begin{array}{c}16.00 \\
(4.00 / 30.00)\end{array}$ & $\begin{array}{c}17.00 \\
(12.00 \cdot 40.00)\end{array}$ & $\begin{array}{c}16.00 \\
(10.00 / 36.00)\end{array}$ & $\begin{array}{c}18.00 \\
(8.00 / 36.00)\end{array}$ & $\begin{array}{c}19.00 \\
(8.00 / 28.00)\end{array}$ & $\begin{array}{c}18.00 \\
(12.00 / 36.00)\end{array}$ & $=0.001$ \\
\hline PS & $\begin{array}{c}3.00 \\
(1.0010 .00)\end{array}$ & $\begin{array}{c}3.50 \\
(2.0011 .00)\end{array}$ & $\begin{array}{c}3.00 \\
(1.009 .00)\end{array}$ & $\begin{array}{c}4.00 \\
(2.00 \% 12.00)\end{array}$ & $\begin{array}{c}4.00 \\
(2.0012 .00)\end{array}$ & $\begin{array}{c}4.00 \\
(2.00: 12.00)\end{array}$ & $<0.001$ \\
\hline Quick-DASH & $\begin{array}{l}4.04 \\
(.00 .70 .45)\end{array}$ & $\begin{array}{l}39.76 \\
(.0070 .45)\end{array}$ & $\begin{array}{l}28.40 \\
(.00 .68 .18)\end{array}$ & $\begin{array}{c}18.18 \\
(.00 .70 .45)\end{array}$ & $\begin{array}{c}4.54 \\
(.00 .68 .18)\end{array}$ & $\begin{array}{c}.00 \\
(.0025 .00)\end{array}$ & $<0.001$ \\
\hline
\end{tabular}

Proksimalinterfalangeal, DIF: Distalinterfalangeal, IQR: Interquartile Range

Conclusions: According to our results; RESWT might be an effective method to decrease pain severity, improve general functional capacity, range of motion, grip strength and pinch strength in patients with trigger finger.

References:

[1] Canale ST. Beaty JH. Canale \& Beaty: Campbell's Operative Orthopaedics, (CD-ROM) 11th Edition. 2008. Philadelphia, Pennsylvania.

[2] Ogden JA, Toth-Kischkat A, Schultheiss R. Principles of shock wave therapy. Clin Orthop Relat Res 2001; 387: 8-17.

[3] Okay B, Mustafa E. Ortopedi ve travmatolojideekstrakorporeal şok dalga tedavisi uygulamaları. C. Ü. Tıp Fakültesi Dergisi. 2002; 24(3):161-164.

Acknowledgements: The authors declare that they have no conflict of interest. Disclosure of Interest: None declared

DOI: 10.1136/annrheumdis-2017-eular.4776

\section{SAT0595 EFFECTIVENESS OF SHORT WAVE DIATHERMY TREATMENT IN PATIENTS WITH SUBACROMIAL IMPINGEMENT SYNDROME AND VALUE OF NIGHT PAIN ON PATIENT SELECTION: A DOUBLE-BLIND, RANDOMIZED, PLACEBO-CONTROLLED TRIAL}

M. Yilmaz Kaysin ${ }^{1}$, P. Akpinar ${ }^{1}$, I. Aktas ${ }^{1}$, F. Unlu Ozkan ${ }^{1}$, D. Karamanlioglu ${ }^{2}$, H. Hartevioglu ${ }^{1}$, N. Vural ${ }^{1}$. ${ }^{1}$ Department of Physical Medicine and Rehabilitation, Istanbul Fatih Sultan Mehmet Training and Research Hospital; ${ }^{2}$ Department of Physical Medicine and Rehabilitation, Sultanbeyli State Hospital, Istanbul, Turkey

Background: Shoulder impingement syndrome (SIS) is a common causes of shoulder pain and the night pain is a frequent symptom of this condition $(1,2)$. Short wave diathermy (SWD) is a deep diathermic agents used in the treatment of 